\title{
Cultura política e valores de cidadania na Região Metropolitana de São Paulo
}

\author{
Edison Nunes \\ Programa de Estudos Pós-Graduados em Ciências Sociais - PUC-SP \\ Núcleo de Pesquisa de Políticas Públicas - USP
}

Félix Sanches

Departamento de Sociologia - PUC-SP

Vera Chaia

Programa de Estudos Pós-Graduados em Ciências Sociais Núcleo de Estudos em Arte, Mídia e Política

PUC-SP

\begin{abstract}
Resumo: O presente artigo tem como objetivo apresentar uma caracterização da cultura política na Região Metropolitana de São Paulo, analisando atitudes e percepções em torno do sistema político; formas de exercício de cidadania e disponibilidade para o associativismo e ação política. Discute duas hipóteses concorrentes, não excludentes: 1) a clássica interrogação de natureza sociológica da relação entre o contexto socioeconômico e urbano e a cultura política e 2) a consideração de tal processo como fortemente influenciado pela história política local e sua conexão com o nacional. Privilegia a experiência política dos cidadãos como variável independente em relação à cultura política e que se apresenta uma causação cruzada entre o marco institucional e os pressupostos pelos quais os agentes formulam suas preferências.
\end{abstract}

Palavras chaves: cultura política; região metropolitana de São Paulo; cidadania; associativismo; ação política

Abstract: The aim of this present article is to make a characterization of the political culture in the metropolitan region of São Paulo, by examining attitudes and perceptions about the political system, forms of citizenship and availability for the associations and political action. It discusses two competing hypothesis, but not excluded: 1) The classic question of a sociological nature of the relationship between socioeconomic context and urban culture and politics, and 2) the consideration of this process as influenced by local and national history and its connections. It emphasizes the political experience of citizens as independent variable in relation to political culture and that presents a causation between the cross-institutional framework and the assumption by which agents formulate their preferences.

Keywords: political culture; the metropolitan region of São Paulo; citizenship; association; political action 


\section{Apresentação}

O objetivo deste artigo é sistematizar os resultados da pesquisa "Cidade, Cidadão e Cidadania", realizada pelo "Observatório das Metrópoles", para o caso da Região Metropolitana de São Paulo, apresentando uma caracterização da cultura política de seus habitantes, suas atitudes e percepções em torno do sistema político; suas representações sobre as formas de exercício de cidadania e sobre a sua disponibilidade para o associativismo e a ação política. Persegue-se aqui a reflexão em torno de duas hipóteses concorrentes, mas não excludentes, a saber, 1) a clássica interrogação de natureza sociológica da relação entre o contexto do desenvolvimento socioeconômico e de urbanização e a cultura política e 2) a consideração que tal processo é fortemente influenciado pela história política local e sua conexão com a nacional. Privilegia, nesse caso, a experiência política dos cidadãos como variável independente em relação à cultura política e que, no processo, apresenta-se uma causação cruzada entre o marco institucional no qual os agentes realizam suas escolhas e seus pressupostos valorativos, cognitivos e afetivos a partir dos quais formulam suas preferências (MOISÉS, 2008). O pressuposto a ser testado é o de que a emergência de uma nova cultura política ${ }^{1}$, associada ao tamanho e complexidade da Metrópole, bem como ao papel que desempenha num sistema mundializado, é realizada através de determinações locais, configurando até certo ponto um devir sui generis, onde o novo reatualiza o experimentado sem excluí-lo.

A pesquisa materializa-se foi realizada através de survey em uma amostra aleatória do universo da população adulta de habitantes de municípios selecionados da Região Metropolitana, mas adverte-se, desde já para a potência analítica da técnica e seu limite, pois presta-se sobretudo à análise das grandes tendências agregadas, abstraindo-se grupos empíricos específicos. Assim fenômenos localizados tendem a desaparecer das estatísticas, embora nelas compareçam seus impactos nos resultados agregados. Da mesma forma, embora seja evidente a grande heterogeneidade da Metrópole e dos municípios que a conformam. internamente e entre sí - clivagens de natureza ecológica como "centro e periferia", local de moradia etc. ou de processos diacrônicos de transformação urbana, como

\footnotetext{
${ }^{1}$ Ver CABRAL e SILVA (2006). Em contrapartida, a literatura é virtualmente omissa - com a importante mas recente excepção de Robert Putnam (2000) - quanto ao efeito-metrópole, isto é, o eventual impacto da vida metropolitana sobre o efectivo exercício dos direitos da cidadania política e das suas modalidades concretas. Mas se Putnam procura na recente tendência para o "urban sprawl" e a suburbanização uma das explicações para a crescente erosão do capital social nos Estados Unidos (2000, p.204-215), outros houve que fizeram o percurso inverso. Com efeito, Terry N. Clark e os participantes no projecto FAUI têm monitorizado durante os últimos trinta anos a evolução da cultura política a nível local, concluindo que as tendências de emergência de uma Nova Cultura Política têm vindo a consolidar-se e até a alcançar o nível nacional dos sistemas políticos. Como é que estas duas teses se ligam?".
} 
a dinâmica demográfica, da violência, da exclusão não são consideradas no presente trabalho. Por tal razão, o artigo exime-se de diálogo aprofundado com a bibliografia que trata de experiência extremamente inovadoras para a cultura política de segmentos determinados da sociedade. Por outro lado, o survey permite a avaliação comparativa das principais características da cultura política da Região Metropolitana com as demais congêneres do Brasil e de outros países. Se a análise pode parecer excessivamente generalizante, tal é o preço da escolha metododológica em sua ênfase na comparabilidade dos dados; os conhecimentos que a pesquisa propicia são assumidos como complementares e não excludentes aos de outras abordagens teórico-metodológicas, cada qual com seus devidos termos de validade.

\title{
Breve caracterização da experiência política em São Paulo A Região Metropolitana de São Paulo
}

\begin{abstract}
"São Paulo, grande metrópole nacional, tem projeção em todo o País, e sua rede abrange o estado de São Paulo, parte do Triângulo Mineiro e do sul de Minas, estendendo-se para Mato Grosso do Sul, Mato Grosso, Rondônia e Acre. Concentra, nos municípios que a compõem, cerca de $28,0 \%$ da população brasileira e 40,5\% do Produto Interno Bruto PIB de 2005. A alta concentração/primazia se reflete no PIB per capita, que é de $R \$ 21,6$ mil para São Paulo, e $R \$ 14,2$ mil para os demais municípios do conjunto" (IBGE, 2008)².
\end{abstract}

Com o texto acima, o IBGE caracteriza a maior Região Metropolitana do Brasil que congrega 19,5 milhões de pessoas, das quais mais de dez milhões concentram-se no município de São Paulo. Sua dinâmica socioeconômica é intensa, propiciando terreno fértil para empreendimentos, serviços e iniciativas. A guisa de exemplo, detém, em março de 2005, 243.927 domínios na Internet, o que representa cerca de $33 \%$ do total no país. Tal desempenho, contudo e como sobejamente conhecido, não elide disparidades de renda e oportunidades de vida para seus cidadãos. Como é explicado adiante, à sua especificidade no contexto das redes de cidades brasileiras corresponde também marcadas diferenças na cultura política.

\footnotetext{
2 "The study Areas of Influence of Cities shows the networks formed by the main urban centers in the country, based on the presence of institutions under executive, legislative and judiciary powers, as well as big companies, higher education institutions, healthcare services and web directories. These networks sometimes overcome the official territory division, strongly affecting even cities located in different federative units". IBGE._Areas of Influence of Cities. Social. Communication. October, 10, 2008.
} 


\section{São Paulo: especificidades em suas características regionais e dinâmica política}

Simon Schwartzman, em "Bases do Autoritarismo Brasileiro" discute a singularidade do estado de São Paulo no processo político, como um centro que sempre se destacou por se opor ao centralismo do governo federal. Os ímpetos de autonomia, de independência e, principalmente, de pressões populares, marcaram a sua relação com o poder centralizado. O estado nunca desempenhou "um papel correspondente à sua importância econômica e demográfica no contexto nacional" (SCHWARTZMAN, 1988, p.64). Desde o início do século XX, constitui a região mais industrializada e moderna do país; no entanto esse desenvolvimento não é acompanhado por um fortalecimento político, o que pode ser demonstrado pela diminuta expressão e força eleitoral no estado dos três partidos políticos nacionais de 1946 a 1964, PTB, UDN e PSD em São Paulo. Sequer a eleição do paulista Jânio da Silva Quadros à Presidência da República, em 1960, pode ser considerada uma exceção à regra; figura idiossincrática, personalista e autoritária, sempre desdenhou a importância dos partidos políticos, os quais utilizava oportunisticamente como ferramentas descartáveis para se chegar ao poder.

A cidade de São Paulo se desenvolveu, comparativamente com Rio de Janeiro, Minas Gerais e Rio Grande do Sul, de forma mais independente e isolada. "Desde o início da história do país, a antiga Capitania de São Vicente se desenvolveu independente de sua administração central" (SCHWARTZMAN, 1988, p.68). A província de São Paulo só começou a se projetar nacionalmente com a expansão do café no século XIX. Com o censo de 1940, São Paulo já era o estado com a maior população do país, que mais arrecadava impostos para União e com maior índice de industrialização. Assim sendo, a história da ocupação e formação econômica e política de São Paulo aponta alguns momentos de insubordinação e confronto com a Coroa Portuguesa e, posteriormente, com o Governo Central após a Proclamação da República ${ }^{3}$.

Quando foi adotada uma política de centralização das decisões econômicas por parte do Estado pós 1930, a elite paulista se movimentou, pressionou o governo para preservar-se dessa nova política aplicada. "Os paulistas queriam, no entanto, era outra coisa. Eles tinham seus próprios patrimônios, e estavam interessados em controlar os mecanismos de decisão, em poder influenciar as ações governamentais no sentido de facilitar e ajudar na consecução de seus objetivos econômicos próprios e privados. Para os paulistas, a política era uma forma de melhorar seus negócios: para quase todos os outros, a política era o seu negócio. E é nisto que reside a diferença e, em última análise a marginalidade política daquele estado" (SCHWARTZMAN, 1988, p.69).

\footnotetext{
${ }^{3}$ Ver também Laura de Mello e Souza (2006) sobre as especificidades da política paulista no séc. XVIII.
} 
O maior colégio eleitoral não é correspondente ao peso que os partidos políticos nacionais tiveram em São Paulo no período de 1946 a 1964. O PTB, a UDN e o PSD eram partidos fracos e, em contraposição a esta debilidade política de São Paulo no contexto nacional surgiram lideranças políticas que expressam o chamado "populismo paulista". Fernando Henrique Cardoso considera a formação desse populismo paulista como uma "perversão do sistema representativo", que teria se originado a partir das limitações do próprio sistema democrático representativo imposto pós 1947 com a exclusão do PCB (CARDOSO, 1975). Por sua vez, Schwartzman sugere que o fundamental na explicação da fragilidade do PTB paulista não é oriundo do controle absoluto de Getúlio Vargas e de João Goulart sobre o trabalhismo, mas a necessidade de se ter uma seção paulista fraca, principalmente devido ao fato de que essa medida de controle impedia a incorporação do setor operário sindicalizado e estruturado, que rompesse com o predomínio do sistema de cooptação na esfera da política desenvolvida em termos nacionais. Conjugada a essa explicação, Maria Vitória Benevides (BENEVIDES, 1981) afirma que a concorrência de outros partidos políticos trabalhistas também era importante no estado de São Paulo, pois coexistiam com o PTB, o PTN (Partido Trabalhista Nacional), o PST (Partido Social Trabalhista), o MTR (Movimento Trabalhista Renovador), o PRT (Partido Rural Trabalhista).

Schwartzman comenta que os partidos não se desenvolveram em São Paulo, em decorrência do fato de que os interesses econômicos das elites ou das organizações sindicais eram atendidos em termos específicos, negociando-se diretamente com o poder central e não necessitando das mediações feitas pelos partidos políticos. A elite paulista considerava as interferências governamentais prejudiciais e ineficientes.

Depois de 1962, o sistema de alianças descaracterizou o sistema partidário, ocasionando a quebra da hegemonia da aliança PSD.PTB em termos nacionais, refletindo em São Paulo, onde o PSP (Partido Social Progressista) e outros partidos políticos menores se destacaram eleitoralmente. O PSP, criado por Adhemar de Barros, surgiu seguindo os moldes do PSD nacional criado a partir do aparelho estatal, e constituiu-se mais como uma estrutura partidária clientelística. Adhemar criou seu partido baseado nas alianças e acordos que angariou enquanto Interventor do estado de São Paulo durante o "Estado Novo", no período de 1938 a 1941. Regina Sampaio considera que o PSP assumiu mais uma característica regional, mas apesar dessa característica "suplantou os grandes partidos nacionais em São Paulo e,... foi um fator de bloqueio ao acesso e estruturação desses partidos no contexto paulista" (SAMPAIO, 1982, p.98).

Para Lucia Hippólito, o PSD viveu todo o período de sua existência (1946. 1965) comprimido entre as duas lideranças paulistas que se projetavam nacionalmente, Adhemar de Barros e Jânio Quadros: "Havia até uma frase muito 
citada naquela ocasião, atribuída a Tancredo Neves, que dizia que o PSD de São Paulo era tão importante que cabia todo na sala de visitas do Cirilo Júnior, conta Pacheco e Chaves" (HIPPOLITO, 1985, p.96). Na avaliação de Schwartzman: "Tanto Adhemar quanto Jânio são pessoas que visam diretamente ao sistema político nacional, mas esta 'nacionalização' da política paulista tem como resultado, precisamente, a destruição do sistema político-partidário nacional sem a criação de um outro sistema alternativo" (SCHWARTZMAN, 1988, p.75). Para Fernando Henrique "Não houve em São Paulo outro líder, senão Jânio Quadros, cuja aversão aos partidos tornava-o incapaz para criá-los, que fosse capaz de agregar estes interesses diversos. E nenhum partido quis ou foi capaz de fazê-lo" (CARDOSO, 1975: 85).

Exemplos mais recentes de políticos paulistas marcantes que guardam características semelhantes são Paulo Maluf e Orestes Quércia. O primeiro foi prefeito e governador em ambos os casos nomeado pelo governo militar, e tornouse prefeito da cidade de São Paulo (1993 a 1997) pelo voto popular. Orestes Quércia foi político ligado ao MDB (Movimento Democrático Brasileiro), responsável pelo crescimento da legenda em todo o país enquanto presidente do partido. Foi governador do estado de São Paulo (1986 - 1990) e ainda mantém, sob seu comando, uma parcela significativa do PMDB, partido reorganizado pós reforma do sistema brasileiro em 1979.

A grande São Paulo foi palco dos movimentos sociais de 1978-79, que surgem como resposta à atuação dos governos militares. As greves trabalhistas e o surgimento do Novo Sindicalismo é produto deste período e fez emergir a liderança política de Luiz Inácio Lula da Silva, Presidente da República entre 2002 -2006 e 2006-2010. São Paulo também foi palco do surgimento do PT (Partido dos Trabalhadores) em 1979 e do PSDB (Partido Social Democrata Brasileiro) em 1988, partidos hegemônicos no momento político atual da sociedade brasileira e que disputam pleitos eleitorais nos últimos anos na cidade e no estado de São Paulo. Considerar que a reprodução em São Paulo da mesma clivagem presente nas últimas disputas para a Presidência da República signifique um abandono da tradição paulista de não alinhamento partidário parece apressada. A emergência do PSDB como a principal força eleitoral nas disputas para o governo do estado é caudatária do desgaste do "malufismo" e da liderança de Quércia. Apenas a exclusão do PMDB e a relativa inexpressividade do PFL/DEM já são indícios comparativos da especificidade da política paulista. Se é lícito generalizar a análise para a cidade de São Paulo ao conjunto da Região, assiste-se a um trânsito entre a antiga polarização esquerda-direita para uma nova caracterizada pela oposição entre esquerda e centro, com um fortalecimento deste último (LIMONGI e MESQUITA, 2008). Conforme os dados da pesquisa, a Metrópole paulista apresenta cerca de $30 \%$ da população auto-declarados "de esquerda", com a grande maioria declarando-se "de centro" e com a quase ausência dos que se consideram "de 
direita". Há coerência, portanto, entre o desempenho eleitoral e o posicionamento, resalvada a observação dos autores supra-citados sobre as flutuações e perturbações possíveis no eleitorado de educação mediana capazes de desfazer o equilíbrio.

Em particular, o surgimento do PT e de movimentos sociais veio agregar alguns elementos peculiares que merecem atenção ao se debater os aspectos mais significativos da cultura política da cidade (SADER, 1988). A emergência do PT na política paulistana e nacional coincide com o crescimento do associativismo como reflexo das mudanças ocorridas no país com a redemocratização (CALDEIRA, 2000) e que introduziram mudanças importantes nas formas de representação e de ação política na sociedade (DOIMO, 1995). Essas alterações nas formas de articulação do poder e da sociedade têm levado estudiosos da cultura política a falar em "sanfona participativa" (AVRITZER, VENTURI \& RECAMAN, 2004) para tentar captar o impacto dos ciclos mais recentes da política paulistana. O associativismo e a participação dos cidadãos aparecem assim como variável sensível às conjunturas políticas e estratégias específicas dos chefes dos executivos municipais da Região e do estado e de suas respectivas oposições na disputa pelo poder.

Parte da bibliografia análitica aponta também, de forma mais radical, a emergência de um traço da cultura política, a saber, uma nova noção de cidadania fundada no "direito a ter direitos" (DAGNINO, 1996; TELLES, 1996). Tal postulação, com forte teor normativo e pertinente a um "projeto político" de uma "(re)criação da própria República", supõe uma livre interpretação do princípio da legalidade, a produção de uma legalidade informal e com jurisdição própria e localizada. Tratarse-ia, portanto, da invenção de uma nova noção de cidadania já não mais fundada no pertencimento a uma comunidade cívica (nacional) mas em redes de sociabilidade sigificativamentes marcadas pelos desdobramentos da economia, da política (sobretudo a macroeconomia dita neo-liberal) e das tensões geradas nas "tramas urbanas" (TELLES e CABANES, 2006).

Haveria pelo menos três importantes tradições culturais participativas presentes na cidade de São Paulo, o comunitarismo cristão, a tradição socialistademocrática e a cultura popular (GUIMARÃES, 2004). "O potencial de crescimento do núcleo associativo dependeria das práticas internas às associações civis e das políticas participativas feitas pelo estado. Os seus momentos de expansão e de contração são definidos em grande parte pelo sistema político" (AVRITZER, 2004; AVRITZER, RECAMAN \& VENTURI, 2004). Seja pela relativa novidade dessas práticas, seja por outras vicissitudes da política paulistana, seu impacto na cultura política ainda parece modesto quando comparado às médias que representam a maioria dos cidadãos da metrópole. 


\section{Indicadores sócio-demográficos da amostra}

A amostra para a Região Metropolitana de São Paulo é formada por 768 entrevistados, sendo a metade deles, ou 384, localizados no município de São Paulo e a outra metade em municípios selecionados da Região metropolitana, um procedimento que nos impede de fazer inferências para o total da Região. Fizeram parte da amostra os seguintes municípios: Barueri, Carapicuíba, Diadema, Guarulhos, Itapevi, Itaquaquecetuba, Mairiporã, Osasco, Ribeirão Pires, Santo André, São Bernardo do Campo e São Caetano do Sul. Contudo, dado o tamanho dos casos escolhidos e sua importância socioeconômica, a pesquisa recobre uma parcela significativa da população regional ${ }^{4}$.

Do total dos entrevistados, $54,7 \%$ são mulheres e $45,3 \%$, homens, todos maiores de 18 anos, distribuídos nas seguintes faixas etárias: i) 32,3\% entre 18 e 29 anos; ii) 31,9\% entre 30 e 44 anos; iii) 23,6\% entre 45 e 59 anos; iv) 10,5\% entre 60 e 74 anos e v) $1,7 \%$ com 75 anos ou mais. A amostra é composta predominantemente pela faixa etária de 18 a 44 anos, perfazendo $64,2 \%$, faixa essa supostamente mais receptível a novas formas de sociabilidade e interessada em novos aprendizados. Quanto ao estado civil, mais da metade é de casados (50,5\%); pouco mais de um terço de solteiros (35,7\%); 6,7\% são viúvos e o restante, $7,1 \%$, são de pessoas separadas ou divorciadas.

Prevalece baixo nível de instrução na população amostrada, o que de resto espelha a situação de escolaridade no país; cerca de 2/3 não completaram o nível médio, que corresponderia aos primeiros onze aos de escolarização. Deve-se notar, contudo, que a Região apresenta um percentual significativo de pessoas que concluem o superior $(10,2 \%)$ em relação ao resto do país. No caso do município de São Paulo este percentual eleva-se para $13,5 \%$, configurando a melhor situação entre as sedes de regiões metropolitanas do país.

A prática religiosa do morador da Região Metropolitana de São Paulo está abaixo da média do conjunto da amostra nacional, sendo que o índice para o município ao inferior da Região como um todo. De fato, a soma daqueles que praticam atos religiosos pelo menos três vezes ao mês (prática religiosa regular e irregular) perfaz apenas 50,6\% na cidade de São Paulo, poco mais da metade, $55,5 \%$. O dado, além de sua importância intrínseca, descreve como dito adiante,

\footnotetext{
4 A pesquisa Cidade, Cidadão e Cidadania foi desenvolvida também em seis países: Canadá; Estados Unidos; França; Suécia; Espanha e Portugal. Para o survey realizado no Brasil em 2008 foram entrevistadas 3.304 pessoas nas Regiões metropolitanas de São Paulo, Rio de Janeiro, Belo Horizonte, Porto Alegre, Recife, Natal e Goiânia. O observatório das Metrópoles - IPPUR/UFRJ e o Instituto de Ciências Sociais da Universidade de Lisboa (ICS-UL) vêm desenvolvendo um projeto comparativo sobre a análise das atitudes sociais e políticas dos brasileiros no marco das redes do Internacional Survey Research Programme (ISRP) e do European Social Survey (ESS). No Brasil, o projeto contou com participação do IUPERJ (AZEVEDO, SANTOS e RIBEIRO, 2009, p.362).
} 
poderoso condicionante do associativismo já que igrejas ou organismos religiosos conformam a mais importante alternativa de participação na Metrópole e, com menor intensidade, no país. A prática religiosa apresenta correlação significativa com i) sexo, sendo as mulheres mais propensas que os homens (teste: $p=0,001$; significativo a $p<$ ou $=a 0,05)$; ii) idade, os mais velhos, mais praticantes $(p=0,04)$ e renda em proporção inversa $(p=0,055)$.

A amostra paulista apresenta elevada renda quando comparada com a média nacional, sendo que mais da metade possui rendimentos mensais familiares superiores a cinco salários mínimos. A tendência é mais acentuada no caso do município de São Paulo onde este número engloba 59,1\%. Contudo, é também a Região Metropolitana de São Paulo que apresenta o mais expressivo índice de rendimentos iguais ou inferiores a meio salário mínimo; nas extremidades da distribuição a Região praticamente dobra as respectivas médias nacionais, sendo que a diferença, no caso daqueles de menor rendimento concentra-se nos demais municípios. Note-se que o segmento inferior na cidade de São Paulo é apenas ligeiramente superior à média nacional. Os dados refletem, assim, maior polarização social que congrega extremos de riqueza e de pobreza, sendo esta última concentrada nos municípios periféricos à capital.

No tocante às classes sociais a amostra pesquisada é caracterizada pela presença de uma classe média expressiva na metrópole e pelo destaque de uma classe alta em alguns municípios da região metropolitana, principalmente em Barueri, cidade que possui vários condomínios de luxo. A autoidentificação dos entrevistados em seu pertencimento na classe média (43,8\%), pode significar uma inclusão subjetiva em um segmento 'genérico', que não se diferencia da média da população. Portanto, nem sempre existe uma correlação entre o enquadramento subjetivo dos pesquisados em determinadas classes sociais e o nível de renda da amostra (Tabela 1). 
Tabela 1

Renda familiar mensal e classe social subjetiva

Região Metropolitana de São Paulo (\%) 2008

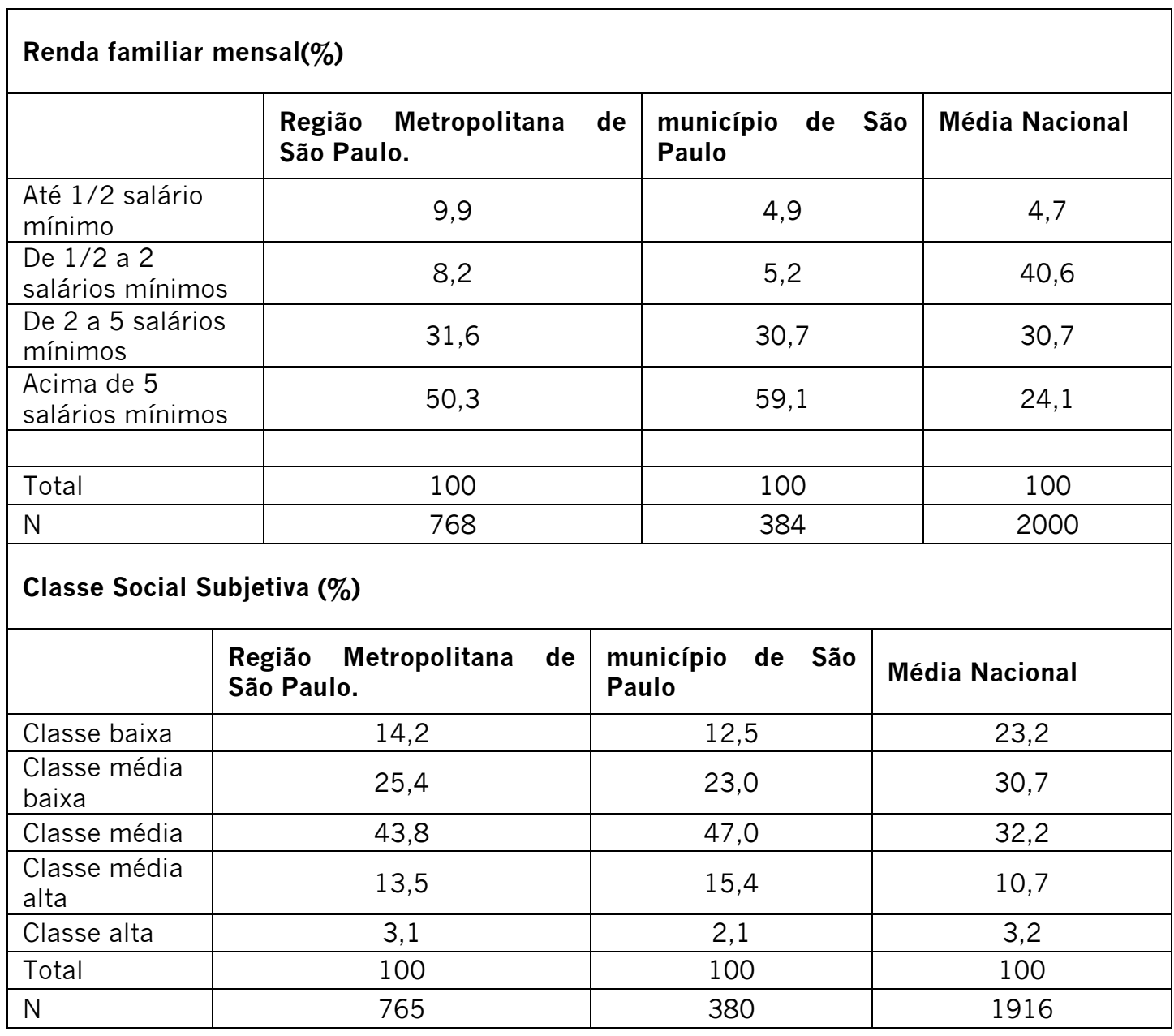

Fonte: Observatório das Metrópoles: Pesquisa "Cidade, Cidadão e Cidadania”, 2008.

Pode parecer curioso que a percepção da posição social do entrevistado não apresente correspondência com seus rendimentos. O indicador de "classe social subjetiva" é construído a partir da demanda aos entrevistados sobre como vê sua posição na escala social, indicando em série de 1 a 10 sua localização. Assim, quanto menor o valor atribuído, maior é a consideração do respondente quanto ao lugar que ocupa na estratificação social; considera-se aqui "classe baixa" os valores 9 e 10; "classe média baixa" entre 7 e 8; "classe média" 5 e 6, "classe média alta" 
entre 3 e 4 e "classe alta", 1 e 2; considera-se pertencendo à classe alta apenas $3,1 \%$ e 2,1\% da amostra, respectivamente para a Região Metropolitana e a capital. Note-se desde já que há mais indivíduos propensos a se colocar em tal patamar nos demais municípios do que no de São Paulo. A mesma observação pode ser feita em relação à classe baixa, onde também o índice da capital é menor. Assim, enquanto a renda familiar tende para polarização, a subjetividade tende para a média; é neste ponto da escala que comparecem as maiores frequências: $43,8 \%$ para a Região e $47,0 \%$ para o município. Mais uma vez, ainda que em gradação suave, a cidade de São Paulo apresenta tendência a se representar longe dos extremos da estratificação: vê a si mesma como uma sociedade de classe média; 60,5\% dos entrevistados colocam-se nas classes média e média-alta.

A distribuição contrasta fortemente com a média nacional que apresenta mais da metade dos casos $(53,9 \%)$ nos dois extratos inferiores, o que poderia estar associado à maior renda dos paulistas. Contudo, o resultado do cruzamento das variáveis "renda familiar mensal" e "classe social subjetiva" revela que quanto maior o rendimento, menor a propensão a se colocar no topo da escala. A Tabela 2 simplifica a anterior por simples agrupamento de valores e dispõe o cruzamento das duas variáveis. Para a Região Metropolitana de São Paulo é clara a relação inversamente proporcional entre renda familiar e auto-imagem de posição social; quanto mais cresce a renda, mais pessoas se declaram pertencer à classe baixa e menor número se posiciona na alta. Note-se que mais de um terço dos entrevistados com renda de até dois salários mínimos (37,3\%) vêem-se pertencer ao topo da pirâmide; no grupo de maior renda, apenas 8,6\%! Fenômeno inverso caracteriza os que se declaram na base da sociedade; somente $3,8 \%$ dos entrevistados que ganham até 2 salários mínimos colocam-se na classe baixa; os de maior renda que se entendem sessa maneira somam $12,1 \%$. Mais uma vez a mesma tendência é observada quanto a acentuação destas características em relação à capital. Pode-se concluir que a percepção de pertencimento aos estratos médios da sociedade associa-se diretamente à variável renda e também à variável ecológica do município de residência. 
Tabela 2

Renda familiar mensal $x$ Classe social subjetiva

Região Metropolitana de São Paulo (\%)

2008

\begin{tabular}{|c|c|c|c|c|c|c|c|c|c|}
\hline & \multicolumn{3}{|c|}{$\begin{array}{l}\text { Região Metropolitana de } \\
\text { São Paulo. }\end{array}$} & \multicolumn{3}{|c|}{ Município de São Paulo } & \multicolumn{3}{|c|}{ Outros municípios } \\
\hline & $\begin{array}{l}\text { até } 2 \mathrm{~s} . \\
\mathrm{m} .\end{array}$ & $\begin{array}{l}\text { de } 2 \text { a } \\
4 \text { s. m. }\end{array}$ & $\begin{array}{l}\text { mais } \\
\text { de } 5 \mathrm{~s} . \\
\mathrm{m} .\end{array}$ & $\begin{array}{l}\text { até } 2 \mathrm{~s} . \\
\mathrm{m} .\end{array}$ & $\begin{array}{l}\text { de } 2 \text { a } \\
4 \text { s. m. }\end{array}$ & $\begin{array}{l}\text { mais } \\
\text { de } 5 \mathrm{~s} . \\
\mathrm{m} .\end{array}$ & $\begin{array}{l}\text { até } 2 \mathrm{~s} \text {. } \\
\mathrm{m} \text {. }\end{array}$ & $\begin{array}{l}\text { de } 2 \text { a } \\
4 \text { s. m. }\end{array}$ & $\begin{array}{l}\text { mais de } \\
5 \mathrm{~s} . \mathrm{m} .\end{array}$ \\
\hline baixa & 3,8 & 7,5 & 12,1 & 2,1 & 4,1 & 14,3 & 5,2 & 10,9 & 6,3 \\
\hline média & 59,0 & 75,9 & 79,3 & 64,6 & 79,6 & 78,6 & 54,3 & 72,3 & 81,3 \\
\hline alta & 37,3 & 16,6 & 8,6 & 33,3 & 16,3 & 7,1 & 40,5 & 16,8 & 12,5 \\
\hline total & 100 & 100 & 100 & 100 & 100 & 100 & 100 & 100 & 100 \\
\hline $\mathbf{N}$ & & & & & & & & & \\
\hline
\end{tabular}

Fonte: Observatório das Metrópoles: Pesquisa “Cidade, Cidadão e Cidadania”, 2008.

Finalmente, relacionando-se a "classe social subjetiva" ao "nível de instrução" obtém-se resultados gerais análogos ao caso da renda familiar; quanto maior a escolarização, pior é a auto-imagem quanto à inserção na estratificação social. Enquanto $34,5 \%$ dos metropolitanos com baixa instrução posicionam-se na classe alta, somente $14,5 \%$ dos que possuem nível superior o fazem. 0 mesmo não ocorre no caso da "classe baixa", sendo que seu número tende a decrescer quanto maior escolaridade até o nível médio (correspondentes aos 11 primeiros anos escolares), voltando a crescer entre os que possuem nível superior. O conjunto das observações novamente é mais nítido no município de São Paulo. Conclui-se daí que o ensino, de forma mais importante que a renda, impacta fortemente a "auto. estima" do cidadão da Região, reiterando o aspecto democratizador da escola. 0 crescimento dos que se dizem pertencer à classe baixa dentre os de nível educacional superior provavelmente pode ser explicado a partir de evidências bastante conhecidas: i) maior informação e conseqüentemente maior exposição ao "efeito demonstração" do modo de vida das classes dominantes em contraste com o próprio; ii) sentimento mais agudo de "incongruência de status", isto é, do julgamento de que a sociedade não lhes premia segundo o status (diploma superior) merecido e iii) identidade político-ideológica com as classes menos favorecidas (é fato sabido que o sistema de ensino universitário é locus privilegiado de recrutamento de partidos de esquerda ou identificados com o movimento "dos trabalhadores"). Porém, mesmo considerando este aspecto, a tendência geral é reiterada; persistente proporção direta entre a autoatribuição nos setores médios e a escolarização formal. 
A compreensão do aparente paradoxo apontado acima, da relação inversa entre renda e escolaridade, por um lado, e classe subjetiva, por outro, supõe a consideração de que a "realidade social" deve ser interiorizada pelos indivíduos nos processos de socialização. Contudo, não se trata aqui de mera reprodução do mundo exterior de maneira passiva: como todo conhecimento, o da realidade social e do lugar que cada qual se percebe nela é uma construção. As representações que daí resultam dependem por certo do contexto social de cada um, das relações materiais nas quais está imerso. Mas, além disso, também dependem de peculiaridades das biografias; dos "outros significativos" presentes nas "socializações primária e secundária"; do conhecimento de "mundos discrepantes" na realidade social, isto é, da possibilidade de vivências bastante distintas de suas próprias. De um modo geral, tais representações são compreendidas na peculiar dialética entre a "divisão social do trabalho (com suas consequencias para a estrutura social) e a distribuição social do conhecimento (com suas consequencias para a objetivação social da realidade)" (BERGER \& LUCKMANN, 1973). Isso significa que quanto maior a complexidade da sociedade, maior a probabilidade da ocorrência de constelações particulares da realidade e das identidades subjetivas. As sociedades abertas, em uma base de mercado, supõem um pluralismo da apreensão da realidade e de processos identitários próprios da modernidade. Em outro diapasão, de valores, carências e modos de vida ${ }^{5}$. O ponto importante aqui é que em tal contexto é mais frequente a assimetria entre a realidade objetiva e a subjetiva, ( 0 que Berger \& Luckmann chamam de socialização mal sucedida). A gradação resultante da relação inversa entre renda e escolaridade, e classe subjetiva - Brasil; municípios da Região Metropolitana de São Paulo; município de São Paulo - parece confirmar a hipótese sociológica do insucesso de parte das socializações.

Dos breves apontamentos teóricos acima delineados pode-se depreender que as variáveis sócio-demográficas determinam um aspecto crucial da cultura política, relativo ao lugar que cada um enxerga pertencer na sociedade. Tal determinação é, contudo, mediatizada pelos "outros significativos" que aparecem nas respectivas biografias dos cidadãos em seus processos de socialização. É prudente lembrar que, dentre estes "outros" que comparecem, sobretudo nos processos secundários, encontram-se lideranças e ativistas políticos; religiosos e professores; pessoal de organizações não-governamentais e lideranças dos movimentos sociais, enfim todo um grupo de pessoas que, de alguma forma, esforçam-se por conquistar o aparato governamental ou influenciar suas decisões. Em palavras curtas: a cultura política, em permanente movimento, é o que se

\footnotetext{
${ }^{5}$ Agnes Heller discute o mesmo problema, com conclusões gerais análogas às de Berger \& Luckmann, na perspectiva marxista da "Escola de Budapeste", em termos da formação da "consciência de nós" em processos com possibilidade de escolhas pessoais de pertencimento a grupos sociais (HELLER, 1981) e dos processos de urbanização, capitalização e modernidade (HELLER, 1985).
} 
disputa na política quando se busca a modificação dos comportamentos através da sedução de "corações e mentes" dos membros do corpo social. Não espanta, portanto, que as variáveis relativas à compreensão política, associativismo, mobilização correlacionam-se mais frequentemente com a classe subjetiva do que com a renda, como discutido a seguir.

\section{Indicadores de atitudes e percepções dos deveres do cidadão em torno do sistema político}

A definição clássica de cidadania é a de um status ao qual associa-se direitos e deveres congruentes ao pertencimento à uma comunidade política (MARSHALL). As percepções sobre esta matéria são, pois, estratégicas para a determinação da cultura política de determinado povo, já que evidenciam a valoração subjetiva da inserção no sistema político e social. Examina-se primeiramente o grau de concordância dos respondentes da Região Metropolitana de São Paulo com deveres do cidadão selecionados: 1."votar sempre nas eleições"; 2."nunca tentar fugir os impostos"; 3."obedecer sempre às leis e regulamentos". 4-"manter-se atento à atividade do governo"; 5."participar nas organizações sociais ou políticas"; 6."tentar compreender diferentes opiniões"; 7."usar produtos bons para a natureza, mesmo que caros"; 8-"ajudar pessoas do país, que vivem pior"; 9. "ajudar pessoas do resto do Mundo, que vivem pior" e 10- "disposto a prestar serviço militar". Nota-se que a Metrópole apresenta os menores valores, na média das respostas, dentre as localidades avaliadas nesta pesquisa: em escala de zero a sete, a região atribui 5,36 de concordância com as "virtudes cívicas".

O conjunto dos "deveres" aqui considerados pode ser dividido em blocos de acordo com o grau de compulsoriedade com o qual o sistema político os trata. Nesse sentido, aqueles deveres cujo descumprimento possui sanção prevista em leis e respectivos mecanismos de controle formam um primeiro grupo. Nele estão as obrigações de votar, pagar impostos, obedecer às leis e regulamentos e prestar serviço militar. No segundo conjunto, o ônus do descumprimento não comparece na forma de coação direta, mas apenas em provável preterimento dos próprios interesses como consequência; tais são os deveres relativos à fiscalização dos poderes públicos e de participação cidadã, bem como a compreensão dos diversos pontos de vista. Finalmente, um terceiro grupo reúne as obrigações cujos beneficiários são imediatamente distintos do agente e cujo descumprimento acarreta, se alguma, apenas sanção moral; tal é o caso do "ajudar pessoas que vivem pior". Nesse caso, remete-se a valores relativos à "solidariedade" e "fraternidade".

Em que pese a obrigatoriedade do voto no Brasil, o que logicamente deveria reforçar este dever, a Região Metropolitana de São Paulo atribui apenas 5,62 ao seu 
grau de importância, sendo que na capital declina ligeiramente; 5,56. À guisa de comparação, países como Suécia, Estados Unidos e Canada exibem médias entre 6,27 e 6,15, sendo a média brasileira 5,68. Dentre as localidades estudadas apenas o Rio de Janeiro apresenta índice ligeiramente menor do que o paulista - 5,40. De fato, a observação deste caso repete-se em relação a honrar os compromissos fiscais - 5,89; obedecer leis e regulamentos - 5,98 e prestar serviço militar - 4,33. Consistentemente a Região mostra índices mais baixos, próximos apenas, mais uma vez, ao Rio de Janeiro. Dentre esses índices, o relativo ao serviço militar, assim como o voto compulsório no Brasil, é o que apresenta maior discrepância em relação ao conjunto da amostra brasileira - 4,33 e 5,05, respectivamente.

Sobre aqueles deveres cujo descumprimento acarreta provável ônus ao agente pela sua consequência, ausente a sanção legal, relativos à vigilância das autoridades e à participação - a Região Metropolitana de São Paulo mantém-se com valores abaixo da média nacional. Uma menor diferença é encontrada no item "tentar compreender diferentes opiniões": com o valor de 5,65, a Região apresenta - $6^{\circ}$ menor índice em sete casos; o mesmo se repete para "manter-se atento às atividades do governo", com um valor de 5,57. Diversamente desses dois primeiros casos, "participar nas organizações sociais ou políticas" e "usar produtos bons para a natureza, mesmo que caros" distancia os paulistas dos demais de forma significativa, seus índices - 4,04 e 4,12 respectivamente - são bastante inferiores dos demais. Parte da explicação para tal comportamento pode ser verificada no fato de que as duas primeiras perguntas referem-se a "valores passivos", de tipo cognitivo apenas, ao passo que as últimas referem-se ao reino da atividade e implica fazer ou omitir algo. Note-se que o custo destas atividades é, via de regra, maior do que os dos casos anteriores e os benefícios correlatos podem ser atingidos muitas vezes sem que se tenha de pagar seu preço. Recorde-se aqui a célebre situação do "free-rider", ou caroneiro, que sabe que, mesmo sem sua participação, receberá seu prêmio de qualquer forma. Reforça a interpretação o fato de que somente no que se refere à vigilância sobre o governo e a compreensão das opiniões distintas, ambos valores de natureza cognitiva, é que o cidadão paulistano supera os demais da Região em suas valorações médias.

Finalmente, a diferença entre São Paulo e os demais casos brasileiros praticamente desaparece no que se refere ao valor da "solidariedade" - "ajudar pessoas do país, que vivem pior"; "ajudar pessoas do resto do Mundo, que vivem pior". O cidadão da Grande São Paulo é ligeiramente mais generoso com os habitantes do próprio país do que com os de outros países. As questões referentes ao auxílio a necessitados dentro e fora do Brasil, induz a que a resposta seja a 'politicamente correta', já que todos devem ajudar ao próximo. 
Tabela 3

Opiniões sobre os Deveres de Cidadania (médias)

Região Metropolitana de São Paulo; município de São Paulo e média nacional 2008

\begin{tabular}{|c|c|c|c|c|c|c|}
\hline & RMSP & $\mathbf{N}$ & Capital & $\mathbf{N}$ & $\begin{array}{c}\text { Brasil } \\
\text { (a) }\end{array}$ & $\mathbf{N}$ \\
\hline 1-votar sempre nas eleições & 5,62 & 768 & 5,56 & 384 & 5,68 & 1946 \\
\hline 2-nunca tentar fugir os impostos & 5,89 & 765 & 5,76 & 383 & 5,71 & 1924 \\
\hline $\begin{array}{l}3 \text {-obedecer sempre às leis e } \\
\text { regulamentos }\end{array}$ & 5,98 & 768 & 5,93 & 384 & 6,12 & 1952 \\
\hline $\begin{array}{l}\text { 4-manter-se atento às atividades do } \\
\text { governo }\end{array}$ & 5,57 & 768 & 5,64 & 384 & 5,68 & 1926 \\
\hline $\begin{array}{l}\text { 5-participar nas organizações sociais ou } \\
\text { políticas }\end{array}$ & 4,04 & 765 & 3,98 & 382 & 4,61 & 1916 \\
\hline $\begin{array}{l}\text { 6-tentar compreender diferentes } \\
\text { opiniões }\end{array}$ & 5,65 & 768 & 5,74 & 384 & 5,74 & 1935 \\
\hline $\begin{array}{l}\text { 7-usar produtos bons para a natureza, } \\
\text { mesmo que caros }\end{array}$ & 4,12 & 767 & 4,04 & 383 & 4,36 & 1864 \\
\hline 8-ajudar pessoas do país, que vivem pior & 6,37 & 768 & 6,30 & 384 & 6,46 & 1957 \\
\hline $\begin{array}{l}\text { 9-ajudar pessoas do resto do Mundo, } \\
\text { que vivem pior }\end{array}$ & 6,04 & 768 & 6,06 & 384 & 6,23 & 1947 \\
\hline 10-disposto a prestar serviço militar & 4,33 & 767 & 4,23 & 384 & 5,05 & 1884 \\
\hline Virtudes cívicas - médias & 5,36 & 768 & 5,32 & 384 & - & . \\
\hline
\end{tabular}

Fonte: Observatório das Metrópoles: Pesquisa "Cidade, Cidadão e Cidadania", 2008.

Uma primeira conclusão que se pode extrair dos dados é a de que o paulista tende a valorar os deveres cívicos, pelo menos em parte, considerando uma análise de seus custos e benefícios respectivos, quando comparados com seus concidadãos das demais metrópoles estudadas. A tendência é mais acentuada no caso dos paulistanos. Em outras palavras, tende a considerar mais intensamente a "racionalidade com relação a fins" em perspectiva egoísta-maximizadora, valorizando em menor intensidade o dever de contribuir para a coletividade. Tal dado é consistente com uma sociedade cética em suas relações interpessoais e nas 
instituições, como discutido. A exceção notável diz respeito aos valores de solidariedade com os mais necessitados. Somente quando a ênfase da pergunta recai na desigualdade, isto é, naquilo que se coloca como antinômico à idéia fundamental de cidadania, quando o outro considerado não pode ser visto como um par e, portanto, nada ameaçador nos esquemas competitivos da sociedade moderna, a Região Metropolitana de São Paulo une-se à excepcional generosidade do brasileiro ${ }^{6}$. Por isso mesmo, talvez se deva pensar que a motivação valorativa expressa-se melhor com o termo "caridade" e, como hipótese, talvez parte do comportamento possa ser atribuído à influência do catolicismo na formação do povo brasileiro.

\section{Dos direitos dos cidadãos}

Para detectar a valoração dos direitos pelo cidadão da metrópole paulista, pergunta-se sobre a importância que atribui a cada um desses itens: 1."nível de vida digno"; 2."autoridades respeitarem direitos das minorias"; 3-"autoridades tratarem todas as pessoas por igual"; 4-"políticos escutarem os cidadãos"; 5-"ter mais oportunidades de participar nas decisões de interesse público"; 6-"participar em ações de desobediência civil quando se está contra ações governamentais". Tais questões recobrem dimensões centrais da cidadania, a saber, a igualdade material mínima que capacita o gozo dos demais direitos, fulcro dos "direitos sociais" na clássica divisão de Marshall, materializados por políticas públicas; as garantias da extensão igualitária dos direitos, pelo respeito ao minoritário e pela isonomia, a própria salvaguarda dos direitos civis; a responsabilidade governamental conjugada com mecanismos de accountability através dos quais os governados posam ser ouvidos e possam ter seus interesses e opiniões considerados nos processos de tomada de decisão públicos e o direito a delas participar. Trata-se, nesse caso, da cidadania política. Finalmente avalia-se também a importância do direito de divergência e desobediência por objeção de consciência.

O comportamento dos dados sobre os direitos apresenta alguma similitude com os referentes aos deveres. A média da Região é a menor dentre os casos analisados. Contudo, deve-se notar inicialmente que, salvo no que se refere à desobediência civil, trata-se de médias bastante elevadas e congruentes com casos de democracias consolidadas e prósperas, denotando grande importância na

\footnotetext{
${ }^{6}$ Comparação entre oito países - Canadá; Espanha; França; Hungria; Portugal; Suécia; Estados Unidos e Brasil - realizada pelo Observatório das Metrópoles, 2008, no bojo da pesquisa "cidade, cidadão e cidadania", aponta o Brasil com as maiores médias quanto a valoração de "ajudar pessoas do país, que vivem pior" (6,46 em escala de 1 a 7) e "ajudar pessoas do resto do Mundo, que vivem pior" (6,23 na mesma escala). No segundo caso, quanto aos habitantes de países extrangeiros, a discrepância é notável.
} 
apreciação dos direitos de cidadania ${ }^{7}$. Uma segunda observação é que a importância dos "direitos", aqui apurados, é consistentemente maior que a dos "deveres", como se não existisse íntima conexão entre ambos. Em terceiro lugar, do direito mais valorizado " "nível de vida digno" - ao menos -"ter mais oportunidades de participar nas decisões de interesse público" a variação observada é relativamente pequena: 6,54 a 6,24, lembrando mais uma vez que o valor máximo da escala é 7. Finalmente, dentro desta margem, pode-se ranquear os direitos, por ordem decrescente de importância, iniciando-se com os direitos sociais, seguido pelo tratamento isonômico dos cidadãos e minorias por parte das autoridades, enfim os direitos civis, e finalmente os políticos representados nos direitos relativos à opinião e participação. No caso da apreciação dos "direitos" não se nota sensível diferença entre a cidade de São Paulo e a Região sendo tendência ligeira do paulistano valorizar mais a igualdade de tratamento dos cidadãos pelas autoridades e, com menor intensidade, dos direitos sociais. Note-se que a racionalidade subjacente parece obedecer ao que foi observado em relação aos deveres: foco maior nos resultados do que nos processos, maximização de benefícios com minimização de custos.

${ }^{7}$ Conforme Observatório das Metrópoles , "Cidade, cidadão e cidadania", 2008. 
Tabela 4

Opiniões sobre os Direitos de Cidadania (médias)

Região Metropolitana de São Paulo; município de São Paulo e média nacional 2008

\begin{tabular}{|c|c|c|c|c|c|c|}
\hline & RMSP & $\mathbf{N}$ & Capital & $\mathbf{N}$ & $\begin{array}{c}\text { Brasil } \\
(1)\end{array}$ & $\mathbf{N}$ \\
\hline 1. Nível de vida digno & 6,54 & 767 & 6,55 & 384 & 6,64 & 1955 \\
\hline $\begin{array}{l}\text { 2. Autoridades respeitarem direitos das } \\
\text { minorias }\end{array}$ & 6,46 & 767 & 6,45 & 384 & 6,46 & 1926 \\
\hline $\begin{array}{l}\text { 3. Autoridades tratarem todas as } \\
\text { pessoas por igual }\end{array}$ & 6,51 & 767 & 6,57 & 384 & 6,66 & 1940 \\
\hline 4. Políticos escutarem os cidadãos & 6,39 & 767 & 6,38 & 384 & 6,55 & 1930 \\
\hline $\begin{array}{l}\text { 5. Ter mais oportunidades de participar } \\
\text { nas decisões de interesse público }\end{array}$ & 6,24 & 766 & 6,23 & 384 & 6,46 & 1929 \\
\hline $\begin{array}{l}\text { 6. Participar em ações de } \\
\text { desobediência civil quando se está } \\
\text { contra ações governamentais }\end{array}$ & 4,34 & 766 & 4,16 & 383 & 3,98 & 1436 \\
\hline direitos dos cidadãos - médias & 6,08 & 767 & 6,06 & 384 & . & . \\
\hline
\end{tabular}

Fonte: Observatório das Metrópoles: Pesquisa "Cidade, Cidadão e Cidadania”, 2008.

Quanto a "participar em ações de desobediência civil quando se está contra as ações governamentais", São Paulo apresenta a segunda menor média dentre os casos brasileiros: 4,34, sendo o dado para o município de São Paulo, 4,16. Destaca-se dentre estes direitos a baixa importância em relação aos outros itens da possibilidade de participação em ações de desobediência civil, o que denota a relativa acomodação dos entrevistados, que esperam sempre que seus direitos sejam atendidos, sem a necessidade de 'brigarem' por estes. Deve-se notar, contudo, que a "objeção de consciência" aplica-se somente a casos excepcionalíssimos, não comparecendo no rol dos direitos básicos de cidadania. Os entrevistados parecem assim entender, posto que valorizam, como visto acima, "obedecer sempre às leis e regulamentos" em patamar bastante mais elevado que o relativo à desobediência. 
A avaliação das autoridades: eficácia e confiança

Contrasta com os valores relativamente elevados de avaliação dos direitos e deveres os minúsculos índices sobre a "eficácia política" e "confiança política". Entende-se aqui por eficácia o grau com que os entrevistados percebem que o governo considera as preferências dos cidadãos em suas escolhas e englobam respostas denotando a intensidade da concordância com as seguintes afirmações: i) "eu não tenho nada a dizer sobre o que o governo faz" e ii) "eu acho que o governo não liga muito para o que pessoas como eu pensam". A concordância é estabelecida em escala de 1 a 5. A Região Metropolitana de São Paulo apresenta o menor valor deste indicador dentre as cidades brasileiras enfocadas $(2,62)$, correspondendo aos paulistanos a média ligeiramente superior $(2,64)$, mas ainda abaixo da nacional $(2,75)$. Considerando-se que a média brasileira é bastante baixa quando comparada com as de outros países, pode-se afirmar que o habitante de São Paulo concebe-se precariamente representado no sistema político, sendo bastante cético sobre as motivações dos representantes. Há, portanto, uma consciência de certa alienação política. Considerando-se que o direito a "ter mais oportunidades de participar nas decisões de interesse público" e o dos "políticos escutarem os cidadãos" é bastante valorizado, como se viu acima, pode-se aventar a hipótese de uma "demanda reprimida" por participação e representação políticas.

Entende-se por "confiança política" o índice pelo qual o cidadão avalia o grau de interesse pessoal dos líderes políticos. Denota a intensidade da concordância com as seguintes afirmações: i) "em geral, pode-se confiar que as pessoas no governo farão o que é certo" e ii) "a maior parte dos políticos está na política para obter vantagens pessoais", expressa também em escala de 1 (concorda totalmente) a 5 (discorda totalmente). Aqui, São Paulo apresenta uma média levemente superior a do país $(1,95)$ e do que as regiões metropolitanas do Rio de Janeiro $(1,92)$ e de Natal $(1,79)$, alcançando o índice de, apenas 1,97 , sendo o cidadão da capital pouco menos cético $(2,05)^{8}$. A representação resultante é a de que os governantes, bem como os políticos em geral, não são proclives ao bem comum e além disso venais! Parte de tal resultado pode ser explicada pelas reiteradas notícias de escândalos políticos, abrangendo praticamente todos os níveis de governo, propaladas pela imprensa. Porém, deve-se também considerar a possibilidade desses dados refletirem a distância entre uma apreciação normativa e outra prática dos problemas políticos. Assim, o regime democrático e as instituições podem ter uma valoração expressiva no plano do "dever ser", bastante afastadas de uma avaliação de sua operação real e presente a depender não apenas

${ }^{8}$ Note-se a congruência de tal dado com a menor valoração dada pelo paulistano, vis-a-vis a Região Metropolitana de São Paulo, aos deveres e direitos relativos à participação; sua tendência a delegar (observando mais atentamente o governo) é ligeiramente maior. 
da vigência da democracia, mas de sua qualidade. Moisés (2008) conclui, precisamente apontando este 'gap', sobre importante "desprezo ou descrédito" de componentes fundamentais da democracia, como o parlamento e partidos no Brasil. A maneira como a própria experiência é interpretada pelo cidadão, sua peculiar vivência de "apartamento" do sistema político e governamental, reatualiza a "incongruência existente entre a oferta institucional de democracia e a demanda cultural dos cidadãos".

Para as hipóteses concorrentes da presente pesquisa cumpre notar que: i) a posição relativa da Região Metropolitana de São Paulo no Brasil pode ser parcialmente explicada pelo tamanho da metrópole (o município de São Paulo possui quase 11 milhões de habitantes; a Região Metropolitana cerca de 19,5 milhões). A suposição aqui, de inspiração em Rousseau, é a da relação inversamente proporcional entre o tamanho do corpo político e a apreciação pessoal da importância que cada qual desempenha no Estado. Em termos mais prosaicos, o que está em discussão é a menor probabilidade de que o cidadão da Grande São Paulo conheça pessoalmente as lideranças políticas, mantendo com elas mais amiúde relações midiatizadas. No caso de contatos pessoais, o mais provável em termos de assiduidade é o momento onde há busca inequívoca de benefício por parte do "político", como no período eleitoral; nos esquemas paroquiais de clientela etc. ii) a peculiar experiência política de São Paulo que, como se viu anteriormente, mantém certa insistência ao não se mostrarem terreno fértil para o arraigamento do sistema nacional de partidos.

\section{Tabela 5}

Eficácia Política e Confiança Política (médias)

Região Metropolitana de São Paulo; município de São Paulo e média nacional 2008

\begin{tabular}{|l|c|c|c|c|c|c|}
\hline & RMSP & N & Capital & N & Brasil & N \\
\hline Eficácia Política - médias & 2,62 & 765 & 2,64 & 383 & 2,75 & 1944 \\
\hline $\begin{array}{l}\text { Confiança política - } \\
\text { médias }\end{array}$ & 1,97 & 763 & 2,05 & 382 & 1,95 & 1951 \\
\hline
\end{tabular}

Escala: 1 - baixa a 5 - elevada. 2. inclui grupos estatisticamente diferentes entre si; inclui a RMSP.

Fonte: Observatório das Metrópoles: Pesquisa “Cidade, Cidadão e Cidadania”, 2008.

Os dados acima são reiterados pelas avaliações dos entrevistados sobre a administração pública e do funcionamento atual da democracia. O primeiro indicador reúne as respostas sobre i) a crença no comprometimento do serviço público em servir as pessoas; ii) sobre o montante de órgãos presumivelmente envolvidos com a corrupção no país e iii) a opinião sobre a probabilidade de 
correção de erros cometidos pela administração. A heterogeneidade do índice inclui, portanto, três dimensões fundamentais ao serviço público; o empenho em cumprir suas funções manifestas; a probidade administrativa e a capacidade do sistema corrigir seus próprios erros (como se sabe, é base para o tratamento isonômico dos administrados). Novamente a média de São Paulo (2,16 em escala de 1 a 4) é inferior à brasileira, sendo a do município pouco mais elevada $(2,20)$. Não espanta, pois, o baixo valor atribuído à democracia experienciada 9 .

A partir de dados do Latinobarômetro, trabalho recente de Moisés (2008) apura um alto grau de insatisfação com a democracia para o conjunto da América Latina, mais ainda para o caso brasileiro, respectivamente $67,6 \%$ e $73,2 \%$, imputando a "baixa qualidade da democracia" no país. Os dados desta pesquisa vão na mesma direção: em uma escala de 1 a 10 em série proporcional à avaliação positiva, o Brasil é pontuado com modestos 5,15; A Região Metropolitana de São Paulo com 4,66 e 4,52 para o município de São Paulo. Note-se que, tanto a "insatisfação com a democracia" como sua baixa avaliação não dizem diretamente respeito ao apego normativo que supõe ser a democracia sempre a melhor forma de governo, mas ao julgamento de seu desempenho atual. Acrescente-se, finalmente, que o índice de avaliação aqui proposto inclui expectativas futuras para os próximos dez anos, afiançando certo ceticismo dos brasileiros em geral, particularmente dos paulistas e paulistanos, em seu aperfeiçoamento.

Tabela 6

Avaliação da administração pública e da democracia (médias)

Região Metropolitana de São Paulo; Município de São Paulo e média nacional 2008

\begin{tabular}{|l|c|c|c|c|c|c|}
\hline & RMSP & N & Capital & N & Brasil & N \\
\hline $\begin{array}{l}\text { avaliação da administração } \\
\text { pública 1 }\end{array}$ & 2,16 & 766 & 2,20 & 384 & 2,28 & 2000 \\
\hline avaliação da democracia 2 & 4,66 & 760 & 4,52 & 380 & 5,15 & 2000 \\
\hline 1) Esç
\end{tabular}

1) Escala: 1 - muito desfavorável a 4 - muito favorável. 2) Escala: 1 - muito ruim a 10 - muito bom.

Fonte: Observatório das Metrópoles: Pesquisa "Cidade, Cidadão e Cidadania", 2008.

9 O indicador é estabalecido a partir das respostas às seguintes perguntas: i) "Como avalia o funcionamento da democracia hoje no Brasil?" e ii) "E daqui a dez anos, como pensa que vai ser o funcionamento da democracia no Brasil". 
Posicionamento político esquerda-direita

Os cidadãos da Região Metropolitana de São Paulo declaram-se majoritariamente de centro $(56,6 \%)$, seguidos por aqueles que colocam-se à esquerda (30,3\%), restando às posições direitistas apenas $13,1 \%$. O perfil é bastante semelhante no caso do município de São Paulo, onde é ligeiramente menor a percentagem daqueles que se declaram à esquerda e à direita: a Metrópole posiciona-se mais à esquerda quando comparada às suas congêneres nacionais, enquanto à direita verifica-se o menor resultado. Na ausência de uma direita expressiva, São Paulo parece polarizar-se, diferentemente do resto do país, entre a esquerda e o centro do espectro político ideológico. Tal índice reflete a peculiaridade de sua história política e, em particular, pela Região ter sido palco do surgimento do Partido dos Trabalhadores. Quanto à essa observação, vale notar que os dois últimos pleitos eleitorais para prefeito do município de São Paulo apresentaram uma votação na coligação de esquerda bastante próxima da distribuição apurada na pesquisa. Na última delas, 2008, o eleitorado comportou-se polarizando a esquerda e o centro, não votando coerentemente a uma clivagem partidária, mas sim por coalizão tópica.

\section{Tabela 7 \\ Posicionamento político esquerda/direita \\ Região Metropolitana de São Paulo; município de São Paulo e média nacional 2008}

\begin{tabular}{|l|c|c|c|}
\hline & $\begin{array}{c}\text { Região Metropolitana } \\
\text { de São Paulo }\end{array}$ & $\begin{array}{c}\text { município de São } \\
\text { Paulo }\end{array}$ & média nacional \\
\hline Esquerda & 30,3 & 28,3 & 20,6 \\
\hline Centro & 56,6 & 58,6 & 52,5 \\
\hline Direita & 13,1 & 13,0 & 27,0 \\
\hline Total & 100 & 100 & 100 \\
\hline N & 710 & 384 & 1569 \\
\hline
\end{tabular}

Fonte: Observatório das Metrópoles: Pesquisa “Cidade, Cidadão e Cidadania”, 2008.

\section{Indicadores sobre formas de exercício de cidadania}

Comparado a outros países, o Brasil é um país com baixo grau de associativismo e a Região Metropolitana de São Paulo não foge desse padrão, apesar de superar a média nacional. $O$ índice de associativismo para a Região, em escala de 0 a 3, é 0,65; sendo o da amostra nacional, somente 0,52!. A forma de organização predominante é a "Igreja ou organismo religioso", com o valor de 1,46. 
Chama atenção também o fato de que os partidos políticos apresentam a mais baixa pontuação, 0,31. O dado corrobora a tese de um fraco arraigamento partidário em São Paulo. Para os demais casos, a cidade de São Paulo participa mais do que os municípios selecionados da região, porém de forma não significativa.

Conforme apontado anteriormente, na história política de São Paulo, em que pesem períodos de grande mobilização, como os representados pelo surgimento do Novo Sindicalismo e a criação do PT, observa-se pouco interesse e pouco engajamento nas diferentes formas de associativismo. $O$ padrão parece ser aquele histórico das antigas oligarquias paulistas, agora incorporado na cultura política das maiorias: de costas às questões coletivas (e ao Estado) desde que seus interesses particulares sejam considerados.

Tabela 8

Associativismo por tipo de organização

Região Metropolitana de São Paulo; município de São Paulo e média nacional 2008

\begin{tabular}{|c|c|c|c|c|c|c|}
\hline & RMSP & $\mathbf{N}$ & Capital & $\mathbf{N}$ & Brasil & $\mathbf{N}$ \\
\hline 1. Partido Político & 0,31 & 768 & 0,31 & 384 & 0,23 & 1982 \\
\hline $\begin{array}{l}\text { 2. Sindicato, grêmio ou associação } \\
\text { profissional }\end{array}$ & 0,53 & 768 & 0,59 & 384 & 0,46 & 1994 \\
\hline 3. Igreja ou organismo religioso & 1,46 & 766 & 1,33 & 384 & 1,18 & 1995 \\
\hline $\begin{array}{l}\text { 4. Grupo desportivo, recreativo ou } \\
\text { cultural }\end{array}$ & 0,52 & 766 & 0,62 & 384 & 0,43 & 1987 \\
\hline 5. Outra associação voluntária & 0,43 & 737 & 0,47 & 369 & 0,27 & 1953 \\
\hline Índice de Associativismo - médias & 0,65 & 768 & 0,66 & 384 & 0,52 & 1998 \\
\hline
\end{tabular}

Fonte: Observatório das Metrópoles: Pesquisa "Cidade, Cidadão e Cidadania”, 2008.

O associativismo é impactado por três variáveis elementares na Região Metropolitana de São Paulo: sexo, idade e renda. No geral, os homens são mais propensos à associação do que as mulheres $(p=0,001$, significativo a $p<$ ou $=a$ 
$0,05)$; os mais velhos em relação aos mais jovens ${ }^{10}(p=0,000)$, embora com pequeno declínio na faixa superior a 50 anos, e os de maior renda sobre os de mais modestos ingressos $(p=0,000)$, também apresentando pequeno declínio entre os que auferem mais de 5 salários mínimos de renda familiar ao mês, apenas no caso do município de São Paulo. Tais dados são coerentes com o que se sabe sobre cultura política, sobretudo a relação bem estabelecida entre renda, associativismo e participação. Pesquisa sobre participação na cidade de São Paulo (LAVALLE \& HOUTZAGER \& ACHARYA, 2004, p.355) chega, contudo, a conclusões contrastantes ao tomar como universo, não o conjunto dos indivíduos da população, mas atores coletivos. Nesse caso, "atores ricos e pobres da sociedade civil parecem igualmente propensos a participar". Tal contraste não implica na informação de nenhuma das teses: tratam de objetos distintos. Assim, o que é verdadeiro para o conjunto das opiniões e comportamentos dos indivíduos de toda a sociedade, pode não ser para uma de suas partes e, ademais, que "atores coletivos pobres" participem igualmente, nada diz sobre a posição na estratificação social dos indivíduos que participam nestas instituições, suas origens sociais etc. Aparentemente trata-se, então, da presença de uma "sub-cultura política" (ALMOND \& POWELL, 1972) própria aos setores sociais que participam em instituições selecionadas ("orçamento participativo" e conselhos gestores, por exemplo) ou da formação de uma "elite sócio-política" com representações, interesses e atitudes, algo distinto do conjunto da sociedade. Há elementos nas conclusões de Lavalle, Houtzager e Achaya nesta última direção: "Surpreendentemente a existência de vínculos com instituições tradicionais da esfera política revelou-se o fator mais influente na participação; os resultados são eloquentes: vínculos com o Partido dos Trabalhadores ou com o governo mediante convênios de prestação de serviços são - juntamente com o fato de um ator da sociedade civil ser coordenadora - os melhores preditores de participação em todos os trés tipos de espaços de participação" (Orçamento Participativo; conselhos de políticas e participação em geral).

A Região Metropolitana e o município de São Paulo apresentam índices de "mobilização" também muito baixos $(0,86$ e 0,91), respectivamente, em escala de 0 a 3), quando comparados com a experiência internacional, embora superior à média total da amostra brasileira $(0,70)$. De fato, o único tipo de ação em que o valor paulista é inferior ao nacional é o "comício político". A distribuição de preferências quanto às formas de ação privilegia um elemento básico do sistema representativo, a saber, a petição ${ }^{11}$ (na forma de abaixo-assinado). O índice

\footnotetext{
10 Adverte-se o leitor a tomar este dado com cautela. Como a escala das respostas pontua generosamente ações pretéritas ("fez em anos anteriores") é provável que o peso da extensa biografia contribua a inflar artificialmente o resultado.

11 Utiliza-se, na Tabela 9, o termo "petição" e não "abaixo assinado" por necessidade de normalização em pesquisa comparativa também aplicada em Portugal. Contudo, cabe esclarecer que os questionários aplicados no Brasil trazem a pergunta com a vocalização brasileira.
} 
apresenta os valores 1,$15 ; 1,56$ e 1,49,respectivamente para o Brasil, a Região e a capital, o que significa um número considerável de pessoas que praticam ou praticaram essa forma de ação pelo menos uma vez na vida. O contraste entre "assinar uma petição" (1,56), por um lado, "Participar num comício" $(0,91)$ e "Contactar político ou alto funcionário do estado" $(0,78)$, por outro - todos diretamente conectados às instituições da democracia representativa - estabelece uma relação associada ao custo pessoal de cada um destes tipos de ação, reatualizando o que está dito acima a propósito dos direitos e deveres de cidadania. O paulista parece fazer um cálculo econômico minimizando o ônus necessário à aquisição de benefícios inerentes à ação política e social, o que, em si, constitui valor. Contudo, deve-se atentar ao fato de que a valorização da ação menos onerosa nada diz imediatamente dos aspectos substantivos das preferências, os benefícios pretendidos podem ser "egoístas" ou "altruístas".

Tabela 9

Mobilização, ação política e social - Formas de ação (médias)

Região Metropolitana de São Paulo, município de São Paulo e média nacional 2008

\begin{tabular}{|l|c|c|c|c|c|c|}
\hline & RMSP & $\mathbf{N}$ & Capital & $\mathbf{N}$ & Brasil & N \\
\hline Assinar uma petição & 1,56 & 754 & 1,49 & 381 & 1,15 & 1958 \\
\hline $\begin{array}{l}\text { Boicotar produtos por razões políticas, } \\
\text { éticas e ambientais }\end{array}$ & 0,99 & 758 & 1,04 & 380 & 0,51 & 1901 \\
\hline Participar numa manifestação & 0,84 & 765 & 0,92 & 383 & 0,76 & 1950 \\
\hline Participar num comício & 0,91 & 765 & 0,92 & 382 & 1,07 & 1953 \\
\hline $\begin{array}{l}\text { Contactar político ou alto funcionário do } \\
\text { estado }\end{array}$ & 0,78 & 766 & 0,86 & 383 & 0,60 & 1934 \\
\hline $\begin{array}{l}\text { Dar dinheiro ou recolher fundo para } \\
\text { causas públicas }\end{array}$ & 0,70 & 763 & 0,78 & 382 & 0,61 & 1966 \\
\hline Contactar/aparecer na mídia & 0,52 & 765 & 0,58 & 383 & 0,45 & 1929 \\
\hline Participar num fórum através da Internet & 0,62 & 765 & 0,67 & 384 & 0,44 & 1934 \\
\hline Índice de Mobilização - médias & 0,86 & 767 & 0,91 & 384 & 0,70 & 1993 \\
\hline $\begin{array}{l}\text { Escala: 0 - nunca o faria; 1 - nunca fez, mas podia fazer; 2 - fez em anos anteriores e 3- fez no último } \\
\text { ano. }\end{array}$ & & & & \\
\hline
\end{tabular}

Fonte: Observatório das Metrópoles: Pesquisa “Cidade, Cidadão e Cidadania”, 2008. 
Ao contrário do que se verifica para o associativismo, a "mobilização" não é influenciada pelo sexo nem na capital, nem nos demais municípios. O índice de mobilização é impactado pela variável renda na Região Metropolitana (teste $p=0,001$, significativo para $p>$ ou $=a 0,05)$ e idade $(0,000)$ de forma que quanto maior seus valores, maior o índice. A isenção importante é que o município de São Paulo não apresenta correlação entre mobilização e renda. Caberia a pergunta do quanto dessa dissociação deve-se às características metropolitanas da cidade. A mobilização é também significativa para a variável "classe social subjetiva" $(0,000)$ que concentra seus valores mais altos entre aqueles que declaram pertencer às camadas médias (como verificado acima, há moderada relação inversamente proporcional entre as médias de renda e as de pertinência à estratificação, de modo que, paradoxalmente, um bom número dos que se dizem pertencer à classe alta, percebe os menores níveis de rendimentos e vice-versa).

A mobilização paulista também destaca-se em outro aspecto importante, apresenta valores consistentemente maiores no que se refere a formas de ação comumente atribuídas à formação de uma nova cultura política: "Boicotar produtos por razões políticas, éticas e ambientais”, com valores para a Região Metropolitana e para a capital de respectivamente 0,99 e 1,04; "Participar num fórum através da Internet", 0,62 e 0,67 e "Contactar/aparecer na mídia", 0,52 e 0,58. Em tais casos, os números aproximam-se daqueles obtidos em países como Espanha, Portugal, França, Suécia e EUA. O dado parece corroborar a tese de Vllaverde \& Silva (2006) do "efeito metrópole": "o eventual impacto da vida metropolitana sobre o efetivo exercício dos direitos da cidadania política e das suas modalidades concretas", como nenhum outro nesta pesquisa.

\section{Indicadores de predisposição para a ação política}

Assume-se aqui que as práticas de associação e mobilização são variáveis que sofrem uma influência recíproca da "cultura política" de seus participantes e da população em geral. Isso quer dizer que a propensão para seu exercício é impactada pelo "padrão de atitudes e orientações individuais com relação à politica compartilhadas por membros de um sistema político" (AMOND\&POWELL, 1972). Por outro lado, tais padrões também são influenciados pela vivência das instituições, da presença de "outros significativos" na vida quotidiana. Pode-se dividir analiticamente o conjunto em i) orientações cognitivas, ou o conhecimento de assuntos e crenças, precisos ou não, certos ou não; ii) orientações afetivas, isto é, sentimentos em relação aos outros e a assuntos políticos e iii) orientações avaliativas, os juízos sobre questões e fatos políticos, o que pressupõe sempre a referência à valores. Ocupa-se, nesta seção, apenas das orientações cognitivas; sobre as avaliativas algo já está dito nas precedentes. 
Orientações cognitivas

O repertório de informações sobre a política de cada um é naturalmente mobilizado quando de suas escolhas e deliberações pertinentes, afetando sua disposição para associar-se, julgar, agir e mobilizar-se. A aquisição básica desse conjunto de saberes ocorre nos processos de socialização, "a ampla e consistente introdução de um indivíduo no mundo objetivo de uma sociedade ou de um setor dela" (BERGER \& LUCKMANN, 1973, p.175), permitindo interiorizar os dados da realidade objetiva e compreender os sentidos subjacentes às atitudes dos outros $\mathrm{e}$ aos próprios fatos. Seu início naturalmente se dá na infância, quando adquire o desenvolvimento elementar que o torna membro da sociedade, normalmente no seio da "família", em situação carregada de emoções; esta é a socialização primária. O processo continua sobre tal base introduzindo o indivíduo a novos setores da sociedade (socialização secundária). Para fins desta pesquisa, trabalhase com um "índice de socialização política primária" ${ }^{12}$ que busca a frequência com que assuntos políticos são ou foram discutidos na família e na escola, com a participação do depoente e de "socialização política secundária", que recolhe a mesma medida para encontros ocorridos em outras esferas como local de trabalho; amigos; sua própria residência ou de familiares; reuniões associativas, ou ainda conversas com vizinhos. Os resultados são bastante baixos, ainda considerando que o seu valor mínimo é 1, que corresponde a nunca conversar sobre política. Quanto à "socialização primária", resulta em 2,06 (escala de 1 a 4) para a média nacional, 2,30 para o conjunto da Região Metropolitana de São Paulo e 2,38 para a capital paulista. Os valores da "socialização secundária" obedecem a mesma gradação sendo, respectivamente na mesma ordem, 2,06; 2,13 e 2,26. Duas observações podem ser estabelecidas; i) o hábito de falar sobre política é mais frequente no município de São Paulo, seguido pela Região, que também possui médias superiores às brasileiras; ii) no caso paulista - município e Região - a família e a escola são espaços que apresentam maior frequência que os demais (média de "socialização primária" superior à "secundária").

A socialização primária não é afetada pela renda familiar nem em São Paulo, nem nos demais municípios da região e tampouco o é pela "classe social subjetiva". O resultado contrasta com o obtido para a "socialização secundária", correlação significativa para ambos os indicadores. Sob tal evidência pode-se dizer que a família e a escola são fatores de homogeneização ou democratização da troca de informações políticas, ao passo que os demais espaços sociais considerados

12 O "índice de socialização política primária" corresponde à média obtida em duas perguntas: i) "Quando o Sr. tinha 14/15 anos, com que frequência falava de política em sua casa?" e ii) "E na escola/universidade, com que frequência se fala, ou se falava, de política?" A Escala varia de 1 - nunca; 2 - raramente; 3 - algumas vezes a 4 - frequentemente. 
tendem a hierarquizar esta oportunidade. Exclusivamente para o caso do município de São Paulo, o mesmo vale para "sexo", tendo a diferença em favor dos homens somente no caso da socialização secundária. Quanto à idade, em nada afeta o índice de "socialização secundária", porém fato auspicioso para a democracia brasileira, mantém correlação perfeita $(p=0,000)$ com a primária; isto significa que as famílias e instituições de ensino da Região são palcos cada vez mais de conversas sobre política. Pode-se mais uma vez afirmar a importância da escolarização na distribuição de oportunidades, minorando os efeitos da hierarquização das estruturas e estratificações da sociedade.

Coerentemente, o grau de interesse pela política, apurado pela pergunta direta em escala de 1-nenhum interesse a 4-muito interesse (valor mínimo=1) também apresenta-se baixo no município e na Região $(2,29$ e 2,20 respectivamente), porém bastante acima de média nacional. Somente no caso da capital associa-se à renda familiar $(p=0,013)$ e à "classe subjetiva" para o total da Região, para o município e para os demais. Conclui-se que o interesse por questões políticas tende a ser maior consistentemente entre os que se julgam pertencer aos setores médios da sociedade. O interesse pela política é maior entre os homens do que entre as mulheres, uma correlação apenas significativa para a capital. Para a Região, o índice também é significativo em relação à "idade" ( $p=0,001)$ formando uma curva cujo pico situa-se na faixa de 25 a 39 anos.

O índice de "compreensão política" reflete a pontuação auto-atribuída pelos entrevistados projetada em escala onde 1 representa baixa compreensão e 5 elevada. O cidadão metropolitano "médio" atribui-se valor de 3,14, indiferentemente se reside ou não na capital; valor bastante superior à média nacional, 2,98. Todos estes valores são considerados baixos em comparação internacional; cumpre notar, contudo, que sistematicamente mais elevados que o grau de interesse pela política. Difícil explicar como pode haver conhecimento daquilo pelo que não se tem interesse! De tal discrepância pode-se aventar a hipótese de que boa parte do "conhecimento da política", disseminado na população, liga-se às representações e valores que fundamentam a insatisfação com as instituições e a democracia, tal como experimentadas e, consequentemente com sua "qualidade", como dito acima. Novamente é a "classe média" a apresentar os mais elevados índices; os de maior renda, o que é acentuado no caso da capital; os homens mais que as mulheres. Quanto à idade, os que têm mais de 40 anos em relação aos mais jovens. 
Tabela 10

Indicadores selecionados de predisposição para a ação política (médias) Região Metropolitana de São Paulo; município de São Paulo e média nacional 2008

\begin{tabular}{|l|c|c|c|c|c|c|}
\hline & RMSP & N & capital & N & Brasil & N \\
\hline Compreensão política-1 & 3,14 & 765 & 3,14 & 383 & 2,98 & 1935 \\
\hline Socialização primária-2 & 2,30 & 756 & 2,38 & 380 & 2,06 & 1979 \\
\hline Socialização secundária-2 & 2,13 & 762 & 2,26 & 382 & 2,06 & 1979 \\
\hline Confiança Interpessoal-2 & 1,97 & 765 & 1,93 & 383 & 1,93 & 1973 \\
\hline $\begin{array}{l}\text { Grau de Interesse pela } \\
\text { Política-3 }\end{array}$ & 2,20 & 760 & 2,29 & 381 & 1,88 & 1954 \\
\hline $\begin{array}{l}\text { 1. Escala: 1 - baixa a 5 - elevada. 2. Escala: 1 - nunca a 4- frequentemente. 3. Escala: 1 - nenhum } \\
\text { interesse a 4 - muito interesse. }\end{array}$
\end{tabular}

Fonte: Observatório das Metrópoles: Pesquisa “Cidade, Cidadão e Cidadania”, 2008.

A "confiança interpessoal" é uma variável importante na avaliação da cultura política, relacionada muitas vezes na bibliografia como fundamental na formação de uma "cultura cívica", ou seja, aquela pressuposta para o funcionamento adequado das instituições democráticas. Entende-se que o "agir em comum" necessita de confiança mútua entre os participantes já que, sem ela, não haveria garantia racional nos resultados dos esforços cooperativos. Invoca-se amiúde o modelo do "dilema do prisioneiro" para demonstrar que a desconfiança tende a produzir ou a solução sub-ótima ou a deserção ex-ante do engajamento. Espera-se, portanto, uma relação direta entre a confiança interpessoal e os níveis de associativismo e mobilização, como resultado da integralidade de tais comportamentos no plano macro-social. Associa-se também a "confiança interpessoal" ao desenvolvimento econômico. Putnam (1996, p.180) chega a afirmar que "boa parte do atraso econômico do mundo se deve à falta de confiança" posto que inerente a qualquer transação comercial. Chega inclusive a explicar a diferença de desenvolvimento entre o Norte o Sul da Itália com base no assim chamado "capital social" que inclui "confiança, normas e sistemas que contribuam para aumentar a eficiência da sociedade, facilitando as ações coordenadas" (PUTNAM, 1996, P.177).

Para avaliar a "confiança interpessoal" dos cidadãos da Região Metropolitana, formula-se aqui um indicador com base nas médias das respostas a duas perguntas: i) "em geral o sr. acha que as pessoas tentarão tirar vantagem do sr. quando puderem ou tentarão ser justas algumas vezes?" (cuja escala é 1 . tentarão tirar vantagem sempre; 2 - tentarão tirar vantagem algumas vezes; 3 . tentarão ser justas algumas vezes e 4 - tentarão ser justas sempre; e ii) "em geral, o sr acha que pode confiar nas pessoas ou, pelo contrário, todo cuidado é pouco?" 
(Escala: 1 - "quase sempre todo cuidado é pouco"; 2 - "algumas vezes todo cuidado é pouco"; 3 - "as pessoas algumas vezes são de confiança" e 4 - "as pessoas quase sempre são de confiança"). O resultado, como esperado, apresenta-se baixo $(1,97)$, porém ligeiramente superior à média nacional e a da cidade de São Paulo $(1,93)$. $\mathrm{Na}$ comparação internacional, é, na verdade, baixíssimo. O ceticismo dissemina-se entre todas as idades e classes sociais subjetivas; significativo em relação ao sexo somente na capital $(p=0,009)$, sendo as mulheres ligeiramente menos desconfiadas, e à renda em toda a Região $(p=0,031)$, de modo que a confiança cresce com a renda; mas, mesmo nesse caso, mantendo valores comparativamente baixos. Ao contrário, para o verificado para "confiança política", onde a capital apresenta indicador mais elevado que os demais municípios da Região, a confiança interpessoal exibe situação oposta.

Os dados corroboram a relação entre confiança, associativismo e mobilização: são todos baixos na cidade de São Paulo e na Metrópole; também coerentes com índices igualmente baixos de "eficácia política"; "confiança política"; "avaliação da administração" e a insatisfação com a democracia. Contrasta, contudo, de sua vinculação ao desenvolvimento econômico. Deve-se, então, questionar a validade universal de que o "capital social", possa ser tomado como causa do desenvolvimento econômico, pelo menos em seu componente "confiança". De fato, a Região Metropolitana de São Paulo, e em particular a capital, destaca-se precisamente pelo seu desenvolvimento, mas não destoa do ceticismo geral da nação. Talvez seja muito provável a coexistência de alta desconfiança e cooperação capaz de gerar crescimento sob certas condições. Deve-se atentar em primeiro lugar a um sutil deslocamento teórico encapsulado no trabalho de Putnam. A confiança requerida para a cooperação pressupõe a expectativa de conhecimento do que o outro fará e não se, sendo-Ihe interessante e possível, tentará "tirar vantagem", "ser injusto". A hipótese aqui é que uma situação de equilíbrio maximizadora das utilidades possa ser obtida, mesmo no interior do "dilema do prisioneiro", se houver um grau razoável de segurança que o outro tentará tirar a máxima vantagem sempre! Nesse caso, certamente, o limite da "vantagem" que se pode obter está condicionado pela capacidade do outro em reciprocar com o mal. Por outro lado, o vínculo de cooperação está garantido no benefício auferido que cada um é capaz de aceitar. O que se sugere então é que as características próprias da cultura política de São Paulo podem preencher, de forma paradoxal, o hiato comunicativo suposto no modelo de racionalidade do "dilema do prisioneiro", permitindo a segurança nas relações entre parceiros que sabem que reciprocamente agirão, se puderem, de maneira injusta.

A extensão da digressão acima justifica-se por tocar em um questionamento importante da cultura política brasileira: a de saber se é possível a prevalência da "ação racional orientada com relação a fins", isto é, "um sistema normativo 
moderno" pela conhecida tipologia de Weber, sob "relações de poder não contratuais" (absolutas). Como se sabe, esta é a base do conceito de "neopatrimonialismo" desenvolvido por SCHWARTZMAN (1988, p.46 e segs.). Em estados onde prevalece tal tipo de dominação, por certo pode haver desenvolvimento do aparelho estatal, racionalização da burocracia pública e privada e desenvolvimento econômico. Também é possível aí a participação política de setores da sociedade, contudo, embricadas em sistemas de "cooptação", em estruturas débeis, sem consistência interna e capacidade organizacional próprias. 0 conflito político em tal caso é limitado em seu escopo, ao estabelecer monopólios de privilégios. Tal sistema pode ser eficaz, sobretudo em relações já dadas e experienciadas onde, a despeito da "desconfiança interpessoal" que embute, fornece a garantia necessária aos parceiros. Todavia há que ceder a Putnam pelo menos nisto: é refratário à inovação quando a solução implicar em preterimento de interesses daqueles que controlam os pontos de imputação de privilégios. Em tal caso, o consenso sobre a mudança dificilmente será alcançado, posto que o imponderável sobre o comportamento do outro joga todos de volta ao "dilema do prisioneiro", sendo a solução sub-ótima a manutenção do status quo, mesmo que com pesadas externalidades para os próprios agentes e a sociedade em geral ${ }^{13}$. Tal mirada corresponde aos índices de associativismo e mobilização aqui apurados, ao grau de desconfiança interpessoal, política e na própria democracia e, finalmente ao achado de Lavalle, Houtzager e Achaya (2004) da dependência da participação em instituições selecionadas na cidade de São Paulo em relação a vínculos com determinado partido político ou com o governo mediante convênios de prestação de serviços.

Finalmente, dentre os aspectos cognitivos relacionados à cultura política, está o hábito de recorrer à mídia para obter informações políticas. Consistentemente, em quase todos os quesitos pesquisados (jornais, televisão, e internet) o município de São Paulo apresenta valores superiores aos da Região, cuja média é o "índice de exposição à mídia informativa", e esta, por sua vez, bem mais elevados que a média nacional. A exceção cabe ao rádio. Os valores são consistentes com as dados acima expostos, que sistematicamente destacam a capital da amostra nacional e, muitas vezes da própria Região Metropolitana.

13 O fato de a maioria dos parlamentares brasileiros considerarem que é necessária uma "reforma política", contrasta com a incapacidade do Legislativo em realizá-la. Sugere-se aqui que este é um exemplo da racionalidade acima descrita, cada um e o conjunto optando pelo custo das externalidades da omissão. 
Tabela 11

Exposição à mídia informativa (médias)

Região Metropolitana de São Paulo; município de São Paulo e média nacional 2008

\begin{tabular}{|l|c|c|c|c|c|c|}
\hline & RMSP & N & capital & N & Brasil & N \\
\hline $\begin{array}{l}\text { 1. Lê assuntos políticos nos } \\
\text { jornais }\end{array}$ & 2,67 & 767 & 2,84 & 384 & 2,22 & 2000 \\
\hline 2. Vê noticiários da televisão & 4,44 & 765 & 4,50 & 383 & 4,10 & 2000 \\
\hline 3. Ouve noticiários da rádio & 2,79 & 767 & 2,92 & 384 & 2,95 & 2000 \\
\hline $\begin{array}{l}\text { 4. Utiliza Internet para saber } \\
\text { notícias e informação política }\end{array}$ & 1,81 & 764 & 1,95 & 383 & 1,37 & 2000 \\
\hline $\begin{array}{l}\text { Índice de Exposição à mídia } \\
\text { informativa - médias }\end{array}$ & 2,93 & 767 & 3,05 & 384 & 2,66 & 1986 \\
\hline Escala: 1 - nula a 5 - total. & & &
\end{tabular}

Fonte: Observatório das Metrópoles: Pesquisa “Cidade, Cidadão e Cidadania”, 2008.

\section{A estrutura da cultura política em São Paulo}

A análise fatorial permite algumas considerações finais sobre as hipóteses testadas. A primeira evidência é a dissociação, em fator à parte, da "tendência partidária" (fator 5) que responde por $8,5 \%$ da variância explicada. Posto que a distribuição não acompanha o conjunto do país, no qual a posição política aparece associada à "confiança interpessoal", resta como explicação a variável local, em particular a experiência de longa data do relativo desenraizamento dos partidos políticos em São Paulo, tendo seu lugar ocupado historicamente por movimentos em torno de lideranças determinadas. Assim, apesar do marco institucional dos municípios brasileiros serem semelhantes, por força dos dispositivos constitucionais, os dados apontam para o fato de que há especificidades ecologicamente determinadas na cultura política, em outras palavras, que esta produz modos específicos de vivência diferencial de instituições análogas.

A distribuição entre os fatores parece sugerir a sedimentação de uma cultura política estruturada vis-a-vis padrões societários modernos, marcados pelo individualismo, por relações impessoais e racionalizadas. 0 fator 1 associa com boa resolução as variáveis "mobilização cognitiva"; "mobilização"; "exposição á mídia"; "interesse na política"; e "associativismo", este último de forma menos significativa; explica 20,5\% da variância. O dado indica, de modo geral, a correlação entre fatores responsáveis pela formação de opinião pessoal, como a informação, seja, esta midiática ou interpessoal, e predisposição à mobilização. Assim, o relativamente alto interesse pela política (2,2 numa escala de 0 a 4, bastante 
superior à média nacional, 1,88) e a compreensão política (na média, 3,14 numa escala de 0 a $5 \cdot 2,98$ para o conjunto do país), embora favoreçam o associativismo, não implicam necessariamente no engajamento em ações coletivas.

Por outro lado, o dado indica que a população ou encontra canais para expressar suas demandas no sistema institucional, ou a sociedade em sentido amplo fornece mecanismos de resolução de problemas eficazes em caráter individual, ou ainda, que a cidadania esteja convencida de que simplesmente não há curso de ação possível para a resolução de necessidades e anseios, configurando uma espécie de demanda reprimida. É possível que as três alternativas anteriores operem simultaneamente, tendo seus pesos relativos impactados por clivagens sociais diversas. De qualquer maneira, esta hipótese descarta de antemão a correlação de tais diferenciações exclusivamente pensadas em termos de estratos socioeconômicos. Renda, classe social subjetiva, confiança interpessoal e "iniciativa e resposta política" conformam o fator 2, com pouca resolução e explicando $11,3 \%$ de variância. Ademais, como anteriormente dito, embora vários dos indicadores sejam sensíveis às variáveis renda e classe subjetiva, não o são sempre conjuntamente e em todos os casos. O que o dado realmente reitera é a relação entre renda mais elevada, autopertencimento às camadas médias, bons preditores de iniciativa política, aliás, segundo as hipóteses mais clássicas sobre participação.

Finalmente, o associativismo aparece conjuntamente com a prática religiosa (boa resolução) com 9,6\% da variância explicada. Note-se que semelhante análise para o total da amostra nacional a coloca lado-a-lado com a posição política, evidência adicional do não enraizamento dos partidos políticos na cultura política de São Paulo. 
Tabela 12

Análise Fatorial das variáveis sóciodemográficas e de cultura política (Rotação Varimax)

\begin{tabular}{|c|c|c|c|c|c|}
\hline & Fator 1 & Fator 2 & Fator 3 & Fator 4 & Fator 5 \\
\hline Mobilização cognitiva & 0,750 & 0,014 & 0,010 & 0,001 & 0,090 \\
\hline Mobilização & 0,748 & $.0,155$ & 0,134 & 0,121 & $.0,093$ \\
\hline Exposição à mídia informativa & 0,733 & 0,235 & 0,126 & $.0,056$ & 0,007 \\
\hline Interesse na política & 0,725 & $.0,062$ & 0,035 & $.0,024$ & $.0,145$ \\
\hline Renda individual mensal & 0,075 & 0,698 & $-0,188$ & $-0,182$ & $-0,140$ \\
\hline Iniciativa e resposta política & 0,339 & $-0,614$ & 0,054 & 0,073 & $-0,108$ \\
\hline Confiança interpessoal & 0,057 & 0,514 & 0,169 & 0,372 & $.0,298$ \\
\hline Classe social subjetiva & 0,121 & 0,445 & 0,297 & 0,014 & 0,213 \\
\hline Faixas de idade & 0,040 & 0,103 & $-0,790$ & 0,109 & 0,249 \\
\hline Escolaridade & 0,261 & 0,067 & 0,727 & 0,014 & 0,214 \\
\hline Freqüência religiosa & $-0,095$ & $.0,037$ & 0,105 & 0,848 & 0,012 \\
\hline Associativismo & 0,500 & $.0,204$ & 0,004 & 0,564 & 0,098 \\
\hline Tendência partidária & $-0,093$ & $.0,023$ & $-0,006$ & 0,032 & 0,888 \\
\hline $\begin{array}{c}\text { Variância explicada } \\
\text { (Total }=60,3 \%)\end{array}$ & $20,5 \%$ & $11,3 \%$ & $10,4 \%$ & $9,6 \%$ & $8,5 \%$ \\
\hline \multicolumn{6}{|c|}{$\begin{array}{l}\text { Notas: Critério de Extração: Keiser - componente com valores próprios } \\
\text { superiores a } 1 .\end{array}$} \\
\hline \multicolumn{6}{|l|}{$\mathrm{KMO}=0,726$ (boa solução) } \\
\hline \multicolumn{5}{|c|}{ Teste de esfericidade de Bartlett $=760,835 ; p=0,000$} & \\
\hline
\end{tabular}

Fonte: Observatório das Metrópoles: Pesquisa "Cidade, Cidadão e Cidadania”, 2008.

\section{Conclusão}

O quanto a centralidade metropolitana responde pela cultura política em São Paulo é algo que não se pode medir ao certo a partir desta pesquisa. Porém, a análise precedente sugere pistas importantes na direção de um "efeito metrópole". Primeiramente, níveis mais elevados de socialização, interesse pela política, associativismo, mobilização, exposição à mídia e similares, inclusive quando comparados ao Rio de Janeiro, dizem algo sobre o acesso dos cidadãos aos recursos necessários, coerentes com a posição de São Paulo no contexto do desenvolvimento nacional. Em segundo lugar, mas não menos importante, o paulista é mais inclinado ao uso de formas de mobilização associadas a uma "nova cultura política": "boicotar produtos por razões políticas, éticas e ambientais"; 
"contactar/aparecer na mídia" e "participar num fórum através da Internet". Em terceiro lugar, tais tendências são exponenciadas no município de São Paulo; algo se deve, portanto, à centralidade.

A "nova cultura política" emergente, pelo menos relativamente ao objeto deste estudo, guarda íntima relação com aspectos tradicionais dos correlativos hábitos dos paulistas e paulistanos, considerando uma mostra representativa dos indivíduos da Região; é eloquente nesse caso o paradoxo de o associativismo político de formas tradicionais, especialmente os partidos políticos, apresentar índices baixíssimos ao mesmo tempo em que outra pesquisa, desta vez considerando atores coletivos, constata alta correlação entre participação e vínculos com o Partido dos Trabalhadores. Do ponto de vista das representações que as pessoas fazem dos objetos políticos, esta pesquisa deixa como conclusão uma pergunta: até que ponto o conjunto de relações - redes, associações vinculadas e movimentos populares - não vivenciam a experiência partidária em São Paulo como um movimento social, a fórmula com a qual desde sua integração, no chamado período populista, faz penetrar suas reivindicações ao estado, reconhecendo-se como povo?

\section{Referências Bibliográficas}

ALMOND, G. A. \& POWELL, G. B. Uma teoria de política comparada. Rio de Janeiro: Zahar Editores, 1972.

AVRITZER, L. (org). A participação em São Paulo. São Paulo: Edunesp, 2004.

AVRITZER, RECAMAN \& VENTURI. "O associativismo paulistano" In: AVRITZER, L. (org). A participação em São Paulo, São Paulo. Edunesp, 2004.

AZEVEDO, S.; SANTOS, O.; RIBEIRO, L. C. "Metrópoles, Cultura Política e Cidadania no Brasil" Cadernos Metropóle, v.11, n²2, São Paulo: EDUC, jun./dez, 2009.

BENEVIDES, M. V. M. A UDN e o Udenismo - ambiguidades do liberalismo brasileiro (1945-1965). Rio de Janeiro: Paz e Terra, 1981.

O velho PTB paulista - Partido, sindicato e Governo em São Paulo: 1945. 1964.CEDEC, 1988.

BERGER, P. L. \& LUCKMANN, T. A construção social da realidade. Tratado de sociologia do conhecimento. Petrópolis: Editora Vozes, 1973.

CABRAL, M. V. e SILVA, F. C. CIDADE \& CIDADANIA: O "efeito-metrópole" sobre o exercício da cidadania política, Lisboa, 2006 (não publicado). 
CARDOSO, F. H. \& LAMOUNIER, B. (orgs.). Os Partidos e as Eleições no Brasil. Rio de Janeiro: CEBRAP/Paz e Terra, 1975.

DAGNINO, E. Os movimentos sociais e a emergência de uma nova noção de cidadania. In: DAGNINO, E. (org.). Anos 90. Política e sociedade no Brasil. São Paulo: Brasiliense, 1996.

DOIMO, A. M. A vez e voz do popular. Rio de Janeiro: Relume Dumará, 1995.

GUIMARÃES, J. As culturas brasileiras da participação democrática. São Paulo: Edunesp, 2004.

HELLER, A. Sociologia della vita quotidiana. Roma: Editori Riuniti, 1981. II potere della vergogna. Roma: Editori Riuniti, 1985.

HIPPOLITO, L. PSD de raposas e reformistas. Rio de Janeiro: Paz e Terra, 1985.

IBGE. 2008. Areas of Influence of Cities. Social Communication, Oct. 10, 2008

LAVALLE \& HOUTZAGER \& ACHARYA. Lugares e atores da democracia: arranjos institucionais participativos e sociedade civil em São Paulo. In: COELHO, V. S. P. \& NOBRE, M. (orgs.). Participação e deliberação. Teoria democrática e experiências institucionais no Brasil contemporâneo. São Paulo, Ed. 34, 2004.

LIMONGI, F. e MESQUITA, L. "Estratégia partidária e preferência dos eleitores. As eleições municipais em São paulo entre 1985 e 2004". Novos Estudos CEBRAP, n. 81, jul. 2008.

OLSON, M. A lógica da ação coletiva. Os benefícios públicos e uma teoria dos grupos sociais. São Paulo: Editora da Universidade de São Paulo: 1999.

PIERUCCI, A. F. O. Janistas e Malufistas em São Paulo (1985-1986): a direita mora no outro lado da cidade, XII Encontro Anual da ANPOCS, Águas de São Pedro, out. 1988.

PUTNAM, R. D. Comunidade e democracia: a experiência da Itália moderna. Rio de Janeiro: Editora Fundação Getúlio Vargas, 1996.

SAMPAIO, R. Adhemar de Barros e o PSP. São Paulo: Global Editora, 1982.

SCHWARTZMAN, S. Bases do Autoritarismo Brasileiro. Rio de Janeiro: Editora Campus, 1988. 
SOARES, G. A. D. Sociedade e Política no Brasil. São Paulo: Difusão Européia do Livro, 1973.

SOUZA, L. M. O sol e a sombra. Política e administração na América Portuguesa do Século XVIII. São Paulo: Companhia das Letras, 2006.

SOUZA, M. C. C. Estado e Partidos Políticos no Brasil (1930 a 1964). São Paulo: Editora Alfa-Omega, 1976.

TELLES, V. S. Sociedade civil e construção de espaços públicos. In: DAGNINO, Evelina (org.). Anos 90. Política e sociedade no Brasil. São Paulo: Brasiliense, 1996.

TELLES, V. S. e CABANES, R. Nas tramas da cidade: trajetórias urbanas e seus territórios. São Paulo: Humanitas, 2006.

Edison Nunes - edison.nunes@uol.com.br

Félix Sanches·frsanche@uol.com.br

vera Chaia·vmchaia@pucsp.br

Recebido para publicação em julho de 2010. Aprovado para publicação em outubro de 2010. 